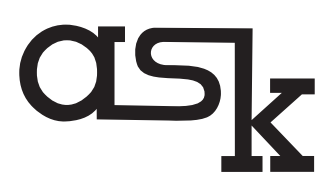

Research \& Methods E-ISSN 2544-0799

ISSN 1234-9224 Vol. 26 (1, 2017): 81-98

The Ohio State University

Columbus, Ohio, USA

Institute of Philosophy and Sociology

Polish Academy of Sciences, Warsaw, Poland

www.askresearchandmethods.org

\title{
Doing Fieldwork on Sensitive Topics: Navigating Memories of Intergroup Violence Committed by Ingroups $^{1}$ in Contemporary Poland
}

\author{
Mateusz Magierowski
}

Jagiellonian University

\begin{abstract}
Sensitive topics in qualitative fieldwork typically include health problems, sexual practices, addictions, illegal activity and death (Campbell 2002; Lee 1993; Liamputtong 2006). Yet, the situation of memories of intergroup violence committed by ingroup members on outgroups - where a community is confronted with the fact that their fellow members have harmed members of other groups - should also be considered as a sensitive topic. An especially sensitive situation occurs when research is conducted in a small community with relatively strong social control maintained through networks of relationships between its members. The aim of this paper is to explore the sensitivity of respondents in their remembering and forgetting of the harm done by members of their own group to the "Others" in local communities, to diagnose the difficulties in conducting fieldwork on this topic, and to present various methods of overcoming them. This article is based on experience from a project dedicated to the social memory of violence committed by Poles against members of other ethnic groups within local communities during World War II.
\end{abstract}

Keywords: sensitive topics; intergroup violence; social memory; forgetting; local communities.

\section{ACKNOWLEDGEMENTS}

The project entitled „Social mechanisms of remembering and forgetting mass murders committed by Poles on members of other ethnic groups. A comparative study of the two local communities", involving research in Pawłokoma and Nieszawa was financed by the National Science Centre (Narodowe Centrum Nauki) as per decision no. DEC-2013/09/N/HS6/00435. Research in Gniewczyna was financed from the Statutory Activity for Young Scientists (DS) funds for tasks benefiting the development of young academic staff and PhD students at the Department of Philosophy of Jagiellonian University (PSP No. K/DSC/001202). I would like to thank Professor Joshua Kjerulf Dubrow for helpful suggestions and comments. 


\section{INTRODUCTION}

Even though the category of sensitive topics has been present in the social research vocabulary for many years, "there is no widely accepted definition of the term", as Tourangeau comments (2008: 812). The expanding subject literature allows for an enumeration of issues that should be considered sensitive topics. These issues include - among others - health problems, sexual practices, addictions, acting against the law, violence or death (Campbell 2002; Lee 1993; Liamputtong 2006). Without question the situation where members of a given group are confronted with the fact that their fellow members have harmed persons from other communities should also be considered as a sensitive topic (see Doosje et al. 2006). An especially sensitive situation occurs when research on the subject is conducted in a small local community with relatively strong social control maintained through networks of formal or/and informal relationships between its members (see Kasarda and Janowitz 1974). The aim of this paper is not only to indicate various aspects of sensitivity in researching social mechanisms of remembering and forgetting harm done by members of respondents' own group to "Others" in local communities, but also to diagnose the difficulties that researchers in this field may face. Based on experience acquired during a project dedicated to social mechanisms of remembering and forgetting Poles' wrongdoings committed against members of other ethnic groups within local communities, the paper also presents the practical methods for coping with these difficulties and for preventing them. The majority of these techniques can be classified among a wide category of methods used during qualitative research to build a rapport between researcher and respondent (see Liamputtong 2006, Dickson-Swift et al. 2007). Consequently, they cannot be treated as innovations shedding completely new light on qualitative research practice, but rather should be perceived as a set of useful recommendations on practical ways to overcome field difficulties during research on a topic which is specific and insufficiently explored.

\section{INTERGROUP VIOLENCE COMMITTED BY INGROUPS AS A SENSITIVE TOPIC IN SOCIAL RESEARCH}

The methodological considerations of researching sensitive topics were addressed in the social sciences as early as in the 1960s by Farberow and his team, who discussed the investigation of taboo topics (Farberow 1963). In turn, Sieber and Stanley advocated addressing sensitive research rather than sensitive topics, using the former term to denote "studies in which there are potential consequences or implications, either directly for the participants in the research or for the class of individuals represented by the research" (1988: 49). Sieber and Stanley's definition did not, however, specify what "consequences or implications" the two authors had 
in mind (Lee 1993:3). This specification can be found in Lee's work on sensitive topics which he discusses in the context of threats related to taking part in this type of research. In Lee's opinion, research on a sensitive topic "potentially poses a substantial threat for those who are or have been involved in it" (1993: 4). He distinguishes three primary categories of threats involved in this type of research. An "intrusive threat" occurs when the research concerns "areas which are private, stressful or sacred" (ibidem). The second category of threats "relates to the study of deviance and social control and involves the possibility that information may be revealed which is stigmatizing or incriminating in some way" (ibidem). The third and final threat occurs during research "which impinges on political alignments, if 'political' is taken in its widest sense to refer to the vested interests of powerful persons" (ibidem).

In view of Lee's proposed typology, a question arises about potential types of threats posed to respondents by local research on the social mechanisms of remembering and forgetting of harm done by ingroups to "Others". Research on this subject may involve a few situations related to two types of threats indicated by Lee. The first situation concerns the threat posed to the positive social identity shared by the members of a given community by referring to this type of event (see Branscombe et al. 2004). Individuals who strongly identify with their own group based on its idealised image may experience discomfort and stress when confronted with this knowledge (Roccas et al. 2004). Consequently, we may consider this to be an "intrusive threat" concerning research on a topic that is stressful to the respondents. A similarly stressful and discomforting experience, albeit for different reasons, may stem from referring to such events in conversation with people who have witnessed harm done by the members of their own group to the "Others". This is because eyewitnesses may experience negative emotional states and severe stress due to the mere act of referring to traumatic images which are inscribed in the autobiographic memory related to such events as murder, rape or genocide (e.g. an image of harm being done to the "Others" or of mutilated bodies of the victims) (see Herve et al 2013). Sometimes, as in the case of some respondents from Pawłokoma, the question about intergroup violence committed by ingroups evoked other sensitive topics from the past, such as harm done to the respondent's family by members of another ethnic group. The sensitivity of the topic of harm done by ingroups towards "Others" is also related to the fact that memories about intergroup violence threaten the interest of some members of local communities. This interest should be understood here as the reputation and good name of groups and particular individuals. In the case of the subject matter, these "particular individuals" are mainly those who participated in the crime and/or their family members as well as those inhabitants who idealize the local community. Potential respondents may not want to talk about such events for fear of revenge, 
or may make false statements about the past, just as in the case of an "intrusive threat" (see Lee 1993: 4). When analysing each of the situations described above, it should be noted that many psychological and social factors may influence an individual's attitude towards the topic - among them public debates which may enhance the tendency to accept the truth about misdeeds (Branscombe et al. 2002: 59). In the Polish context the debate about Jan Tomasz Gross's book Neighbors ([2000] 2001) is considered as most influential, evoking transformations in public discourse and collective memory (see Czyżewski 2008, Forecki 2010, Sułek 2011).

Summarising the above theoretical considerations, it should be stated that research projects on local (non-)memories of harm done by ingroups to the members of other ethnic groups can be treated as a unique area of sensitive research in the sense of Lee's terminology. This kind of research is potentially "multidimensionally sensitive", evoking not one but various types of sensitive situations. The source of the sensitivity may differ depending on the respondent's identity, his life experiences, and the social position he occupies. It may be rooted in the individual's traumatic past (witness trauma), his attachment to a positive image of the reference group, or in the local structure of power and interests. All of the aforementioned situations may generate considerable problems in the collection of data. The paper will show what kind of difficulties researchers can face in a project dedicated to social mechanisms of remembering and forgetting crimes committed by Polish inhabitants in three localities in Poland.

\section{RESEARCHING ATTITUDES TOWARDS THE "DIFFICULT PAST" IN POLAND: PAST EXPERIENCES. METHODOLOGICAL DETAILS}

Before presenting the methodological details of my study, I will briefly examine the experiences of social scientists conducting sensitive research on Poles' attitudes towards the "difficult past"2. The results of this analysis prove that 1) such research situations may generate various difficulties during the data collection process, and 2) there are still some areas within that field which have not been sufficiently explored. Existing studies referring to Poles' social memories of the "difficult past" are in numerous cases a matter of discourse analysis or analysis of the results of national surveys. Researchers conducting such studies highlight the difficulties in obtaining opinions on this topic. Describing the results of a nationwide survey, Piotr T. Kwiatkowski (2008) pointed out that in 2003 only $1 / 3$ of all respondents were able to list characters and events from the Polish national past that one could be ashamed about. He interpreted this outcome as a result of Polish unwillingness to foul one's own nest (Kwiatkowski 2008: 291-292). Polish sociologists, anthropologists, and even historians have also conducted qualitative studies on various potentially sensitive issues related to the difficult Polish past, 
although they were not exclusively dedicated to the topic of misdeeds committed by Poles against "Others". One such pioneer study, focusing on the perception of Jews and on Polish-Jewish relations, was conducted by the historian Alina Cała in the 1970s and 80s. She published the results of her research in the often-cited book The Image of the Jew in Polish Folk Culture ([1995] 2005). Describing the fieldwork experiences of her research team, Cała highlighted the relatively open attitude of respondents to the topic of the research, pointing out that she and her co-researchers faced no serious difficulties related to unwillingness to participate in the study (Cała 2005: 170). However, when comparing this statement to other fieldwork experiences, we should notice that the most "problematic" aspects of Cała's research regarding experiences as witnesses to the Holocaust could not evoke such an intensive feeling of threat as issues brought up during a study focused on acts of open violence against "Others". The topic of unwillingness to participate in a potentially sensitive study was touched upon by the anthropologist Joanna Tokarska-Bakir, who conducted research on anti-Semitic attitudes and blood libels in the Sandomierz area. The results of the study were presented in her extensive monograph Legendy o krwi. Antropologia przesadu (Tokarska-Bakir 2008). In her book she claims that the most difficult phase of the research was the final one, when potential respondents were already aware of the presence of the researchers in the area and did not want to talk with them (ibidem: 399). However, she says nothing about techniques for dealing with this problem. It is worth noting that many interesting data about difficulties resulting from the sensitivity of the topic of misdeeds committed by Poles against "Others" can be found in Anna Bikont's report My z Jedwabnego (Bikont 2004). Although this is a journalistic investigation rather than a scientific sociological study, Bikont shows precisely on the basis on her own field experiences how difficult the process of discovering local knowledge about such events is. In her book about the crime committed by Polish inhabitants of Jedwabne against their Jewish neighbours in 1941, she shares examples of inhabitants' fears and anxieties, evoked by the need to defend their positive group identity and by threats formulated by the perpetrators and their descendants. Her book became an important inspiration for me during the work on the conception and plan of my own research. The study was conducted in 2013 and 2014 with the support of a co-researcher in three localities where Polish residents took part in crimes committed during World War II against members of other ethnic groups: Jews (Gniewczyna), Ukrainians (Pawłokoma) and Germans (Nieszawa). The triangulation of data sources was the first step towards ensuring that data collected was of high quality. Between 28 (Gniewczyna) and 39 (Nieszawa) individual in-depth interviews were held in each location with three categories of respondents: current and former leaders of the local community (representatives of local self-governments, priests, teachers), other members of the community, 
and external experts who had a unique knowledge about it (e.g. journalists or historians). The representatives of each of the three categories of respondents displayed different interests, occupied various positions in the social structure and had different social backgrounds and past experiences. Consequently, they had different viewpoints on the topic and different amounts of knowledge about its various aspects. Data obtained from the interviews with the three categories of respondents, complemented with the acquired secondary data (materials stored in historical archives, legal acts and press materials), allowed the most complete information to be obtained. Furthermore, the triangulation of data sources enabled a comparison of information obtained from different sources, thus ensuring the quality of the data that would form the basis for later analysis.

The author decided not to include focus group interviews (FGI) in his research for two particular reasons. First, recruiting participants for individual interviews would have involved logistical difficulties. Attempting to convince an appropriate number of respondents to participate in research during which they would be asked to talk about a sensitive topic in the presence of other persons would have involved a high risk of failure. The second reason was methodological in character and stemmed from the limitations of the research technique: even if an appropriate number of participants were to be recruited for group interview, the presence of other persons would likely make some participants withdraw from the interview or respond dishonestly.

\section{DIFFICULTIES RELATED TO SENSITIVITY IN RESEARCH ON THE "DIFFICULT PAST" IN LOCAL COMMUNITIES AND HOW TO COPE WITH THEM}

\subsection{Expressions of unwillingness to participate in the study}

The sensitivity of the research and the related feeling of being threatened motivated reactions among respondents that indicated their unwillingness to participate in the study. Some persons who did not want to talk openly about this topic declared either implicitly or explicitly that the reason for their decision was the potential threat that sharing information about a "difficult past" could bring:

The next generation lives, some even hold important positions (...) better not to say anything. (Nieszawa)

[Talking] could be bad for you. (Gniewczyna)

There's a lot of things you wouldn't want to talk about. (Nieszawa)

I'm not going to talk about these subjects. No, I have nothing to say about it. (Gniewczyna) 
Among the reasons for respondent's unwillingness to participate in the research were also those that did not directly indicate that the respondents felt threatened by the consequences of discussing the subject researched. In some cases, however, observation of the respondents' behaviour during recruitment suggested that excuses related to a lack of time or knowledge may have sometimes served as a convenient "mask" behind which the respondents hid fears related to the threats they could potentially face following their participation in the study. One of these excuses was age: persons from young and middle-aged generations suggested asking older persons who might remember the events in question ("Older people might tell you more" or "I'm too young for this"). In turn, some elderly persons refused by indicating memory problems, such as one respondent in Gniewczyna who stated that she had forgotten about "these issues", as she was already over 70 years old. Other potential respondents explained their refusal with the apparent uselessness of their knowledge for academic research ("There's nothing I could tell you", "I'd only make a fool of myself" or "What do I know? I don't read books like you do"). The author and his co-researcher attempted to convince potential respondents to participate by detailing the aim of the study. They explained that the aim is not to test whether their knowledge is historically accurate, but to get to know how different generations within the community remember these events and how this memory is being transmitted. They also emphasised that every opinion or piece of information shared during the interview would be valuable. Sometimes, as with an elderly respondent in Nieszawa who was reluctant to talk and claimed not to remember the war, the researcher asked a direct question about what the respondent had learned about the period from their parents:

Researcher: What do you think is the most important event in the history of Nieszawa?

Respondent: I don't know, I don't remember the war, you see.

Researcher: What have your parents told you about the war, then?

In some cases, the respondent could be convinced to talk after being assured that the interview was anonymous, as in the case of an elderly respondent in Gniewczyna who shared her knowledge about a Jew living nearby who had been murdered during World War II:

Respondent: For example, [my neighbour] told me that she saw herself that... Perhaps I shouldn't be talking about this...

Researcher: Please don't worry, this is completely anonymous. 
Respondent: This is anonymous... She was in the wheat field, when she saw her friends leading a Jew, pushing him in his back, onwards, and she said, "Yeah, I bumped into them, and (...) I didn't know what to do, because I was scared".

The aforementioned methods for convincing the respondents to participate in the discussion sometimes still proved insufficient and the author and his coresearcher had to use other strategies.

\subsection{The key role of trust and the feeling of "fair exchange"}

As with studies on other types of sensitive issues (Liamputtong and Ezzy 2005; Liamputtong 2006; Dickson-Swift et al. 2006, 2007) a key factor in obtaining information was building rapport with the respondents and their trust in the interviewer and making them feel that the talk was an exchange that both parties could benefit from. This relationship of mutual trust was built using two methods. First, in some cases the conversation was directed for some time towards issues that the respondents would talk about more willingly than about harm done by ingroups, or they were simply allowed to move on freely to topics they found important. By listening with kind interest to what the respondents had to say about topics they themselves were willing to address, the researcher worked towards what Daly (1992: 5) calls a "fair exchange". The researcher obtained the information sought, and the respondents could satisfy their need to be listened to. It is especially important to note that in such a context, the person who listened was not a member of the local community who shared respondents' worries and who had listened to the respondents' stories on numerous occasions, but someone "Other", who declared their willingness to listen. Especially popular among "off-topic" issues addressed in interviews, particularly among the young and middle-aged generations, were socioeconomic problems of a given region and the resulting difficulties in the lives of the residents. Elderly respondents were especially inclined to talk about their memories of their families' pasts, as with a respondent from Gniewczyna:

Respondent: (...) My father wasn't with the partisans, but he survived the war, he told me a lot of things.

Researcher: What did he talk about?

Respondent: (...) He wasn't able to go to school. Those were illiterate people, that generation, secondary illiteracy. All he could do was sign his name, because when he was five or six he had to keep an eye on the cows, (...) there were no schools because of the war, and then not everyone could afford school, people went to school if they could. 
The second strategy for building trust was reciprocity of disclosure, which authors such as Daly (1992) and Dickson-Swift et al. (2007) consider a useful tool in research on sensitive topics. Researchers' opinions on various "off-topic" issues or non-intimate information about themselves was designed to construct a particular image of the researcher in the respondent's mind. The image presented the researcher as a partner in an honest exchange for both parties to engage in, rather than a one-sided, depersonalised "information drain". This "revealing of oneself" not only helped to emphasise the researcher's wish to participate in a "fair exchange", but also allowed the respondent to view the researcher as a human being like themselves. Such themes were also introduced to the interview in order to eliminate the hierarchic nature of the researcher-respondent relationship (Liamputtong and Ezzy 2005, Dickson-Swift et al. 2007). This hierarchic nature stems from the disproportion between the social position of the researcher, who states his membership in the academic environment at the very beginning of the interview, and the status of the respondent, who usually has had a lower level of education. Information the author of this study and his co-researcher shared with the respondents depended on the age of the respondent and the "off-topic" subjects they wished to address. In the case of younger generations, the researchers followed the "reciprocity of disclosure" rule by sharing their own experiences related to issues such as the cost of living:

Respondent: How's anyone supposed to make a living from farming... It's impossible! And the kids need to go to school... Do you know how much university studies cost?

Researcher: You're right.

Respondent: A studio flat in Krakow [costs] 1500 zloty per month, or something along those lines.

Researcher: Yeah, if you want to live alone, that's how much you'll have to pay. But if (...), you know, you live with some flatmates, the rent can go down even to a few hundred zloty. But living is expensive now, even food isn't cheap.

Respondent: Exactly!

How long it took to discuss issues not directly related to the subject matter during the interview depended on each respondent's individual characteristics. Some respondents were open enough for us to be able to talk only about the subject matter, while other respondents required a short off-topic conversation to become open. On the other hand, reluctant respondents required greater effort to build trust through a conversation about issues they found important. 
Conducting an interview according to the methods of trust building sometimes allows the gathering of information that the researcher would probably not be able to obtain without their implementation. The interview uses trust-building strategies, thus making it easier to obtain information effectively about sensitive topics when various limits prevent the researcher from engaging in a long-term process of building rapport.

\subsection{The respondent as an expert and the top-down approach ("the funnel procedure")}

The distance between the researcher and the respondent could also be reduced by a deliberately applied strategy whereby the respondent was given the position of an expert in possession of information that was unique from the researcher's point of view. Sometimes it was helpful during the interaction with a respondent for the researcher to deliberately present himself as someone with only superficial knowledge concerning the local community and its history, even if the researcher actually knew the details fairly well. Applying this self-presentation strategy helped the respondent realise that they had important knowledge for the researcher, and to dispel the myth of the "omniscient scientist" entertained by some of them. As a result, the relationship between the researcher and the respondent became more egalitarian and, simultaneously, the respondent was tempted to take the position of expert and guide to the local reality. A resident of Nieszawa, initially anxious about the topic of the "difficult past", was unable to resist this temptation:

Researcher: Have, say, your grandparents ever told you what happened here, in Nieszawa?

Respondent: Is this about the war?

Researcher: About the war, yes.

Respondent: About the murders, too?

Researcher: Was someone murdered?

Respondent: The kids.

Researcher: Where?

Respondent: Come [leads the researcher towards a building where Germans from Nieszawa were held before death].

Researcher: Who [did] this, exactly?

Respondent: There was this guy called ...

A similar strategy was used in an interview with a resident of Gniewczyna who was reluctant to talk about the "difficult past". To convince her to share her 
views on a book by a fellow resident of Gniewczyna, Tadeusz Markiel, in which he openly condemns harm done to Jews by local Poles, the researcher deliberately feigned a lack of familiarity with the book:

Researcher: So was there anyone around here interested about the history of Jews, how they lived and so on?

Respondent: There used to be this Markiel, but he wrote such things that it was just shameful for our Gniewczyna.

Researcher: Why shameful? What did he write about, exactly?

Respondent: He's also dead already. Anyway, he smeared Gniewczyna all over. He brought up only bad things (...). I didn't read the book myself, I've only heard things, because no one wanted to talk about it and said that everything there is just not true.

While in the second example, the aforementioned self-presentation strategy was used only several minutes after the start of the interview, in the interview with the resident of Nieszawa the researcher employed it right from the start, allowing him to lead the conversation according to the shortened version of the "funnel procedure". Using that procedure the researcher encouraged some respondents to participate in the study by stating that the aim of the research was to investigate how the members of the community perceive local history, which was true in the context of the assumed research aims and questions. Next, the researcher asked about the most important characters and events in the history of the town/village according to the respondent, allowing for a free answer and sometimes asking additional questions with interest. If the respondent mentioned characters or events from World War II, the researcher maintained this direction. If not, he asked whether the respondent had heard what happened in the town/village during World War II, as this was when the crimes in each of the three localities happened. If the respondent still did not bring up the "difficult past" at this point, the researcher asked them whether they had heard about the event:

Researcher: What are, in your opinion, the most important people and events in the history of Gniewczyna?

Respondent: General Chruściel.

Researcher: Do you remember anything else from World War II?

Respondent: I'm not old enough to remember.

Researcher: I mean, have you heard from someone about it?

Respondent: Like I told you, General Chruściel comes to my mind the most. 
Researcher: General Chruściel. There was also this story in a book published by some guy from Gniewczyna.

Respondent: I think I know who you're talking about. It's about the Jewish history.

Beginning the interview in this manner in some cases helped avoid opening with threatening topics and introduced respondents to the subject of the study. The conversation was directed to increasingly more specific topics in a top-down manner (the local past in general - local World War II history - the "difficult past"). As a result, questions about harm done to the "Others" by local Poles may have seemed a logical consequence of the previous questions. By preparing respondents for a discussion about the "difficult past" and introducing them into the subject of the study right from the start, the researchers were able to increase the likelihood of obtaining the information they were interested in. Moreover, the procedure provided additional information by allowing the researchers to learn the canon of the local collective memory, and how important the "difficult past" is within that canon.

\subsection{Fieldwork logistics: the role of place and time}

In addition to triangulation of data sources and to strategies employed during interviews, issues related to the logistics of the research such as the time and location of interviews also played an important role in gathering the most complete and credible data possible. The study was conducted in three Polish localities Gniewczyna, Pawłokoma and Nieszawa. The members of such communities sometimes view a researcher as a stranger, or even an intruder. News about the stranger's presence and the subject of interviews can travel quickly within small local communities. This may cause some respondents to feel threatened and discourage them from taking part in the study even before the researcher asks them to, especially in localities where the "difficult past" is a strict taboo. Taking this into account, fieldwork lasting more than several days in a given community sometimes may entail a growing risk of news spreading throughout that community about the study and the related threats. Such brief fieldwork sometimes may be insufficient to collect a satisfactory amount of research material. This issue may, however, be solved by dividing the study into two stages, each of several days, taking place a few months apart. This minimises the rate at which the news spreads throughout the community, helps to "dampen" potential emotions about the presence of the researcher and provides enough time to analyse the collected material, evaluate the fieldwork and arrive at more effective means for data gathering based on conclusions drawn from the research. An evaluation of the researchers' work revealed how the venue of the interview may affect the quality of the data obtained. 
The respondent's home was, without a doubt, from the perspective of the researcher the most comfortable venue for the interview. Interviewed in their own safe space and aware that no third parties could witness their conversation with a "stranger" about the "difficult past", the respondents relatively often shared some pertinent information. Unfortunately, they would rarely invite the researcher in a person they did not know and whom as a result they could not fully trust - which came as no surprise. Sometimes the respondents, when asked to participate, would agree to an interview by the fence of their residence. By remaining within the boundary of their residence, in their own safe space, and preventing the "stranger" from entering, the respondent was able to stop the interview at any time, without having to ask the researcher to leave. Respondents were frequently recruited in relatively crowded places, such as the town square, the river promenade (Nieszawa) or near a shop or health centre (Gniewczyna and Pawłokoma). While ever there were some other people there, recruitment in these places involved "social visibility", which may have intensified potential threat. Intensified feelings of being threatened may stem in such situations from the awareness of a higher risk of identification by other members of the community as a person who, by discussing the "difficult past" with the researcher, sullies the good name of the community and/or undermines the interests of some of its members. This fear was apparent in the behaviour of a respondent from Gniewczyna who was interviewed near the local cemetery. During the conversation, she would look behind her from time to time to see if anyone was coming, and if someone passed by, she would lower her voice.

\subsection{Ethical challenges}

Difficulties related to the data gathering process are not the only difficulties that a researcher of socially conditioned processes of remembering and forgetting a "difficult past" may face (although they are the most important ones from the viewpoint of this article). It is impossible to discuss the difficulties of researching this subject without mentioning ethical challenges, particularly because they often affect methodological choices during the research process. During sensitive studies, researchers are ethically motivated to take actions aimed at decreasing the discomfort and the threat that this type of study involves. These actions should especially be taken in the case of threats related to endangering the interests of certain members of the local community by revealing a "difficult past", as well as in the case of threats related to the trauma of witnessing dramatic events. Actions that a researcher can take to minimise respondents' anxiety about endangering the interests of other members of the community frequently coincide with those that help obtain the most credible and complete data possible. For instance, the 
researchers took care to hold the interviews in a place that is relatively comfortable for the respondents, to indicate that the requested information will be used only for scientific purposes, and, most importantly, to emphasise the anonymity of the research. The anonymity of the research was sometimes further underlined by stating that potential quotations of respondents in a book or an article would only indicate their place of residence, approximate age (potential quotes "about 50 years old"), and gender. In the case of eyewitnesses, we attempted by introducing less emotionally engaging topics into the interview to alleviate any feelings of being threatened caused by bringing up traumatic memories.

\section{CONCLUSIONS}

Empirical data gathered during my research prove that memories of intergroup violence should be treated as another area of sensitive research. In the first, theoretical, part of my paper I have distinguished three situations in which such subject matter evokes fear and discomfort: a threat to the positive collective identity; a threat of revenge for the popularisation of knowledge about the "difficult past"; and witnesses' trauma. As the generation of eyewitnesses has been dying out, we had to deal more often in the course of my research with fear evoked by identification threats or threat of revenge rather than anxiety related to such trauma. Some of the methods we have implemented during the fieldwork to persuade potential respondents to take part in the research are of a universal nature: it is not only researchers dealing with sensitive topics who take such actions as assuring respondents about the anonymity and confidentiality of the research or as convincing them that every opinion is important regardless of the respondent's age or education. During the process of preparation of other methodological tools enabling us to deal with the problem of the sensitivity of my research, particular attention to the issues highlighted in the methodological literature on sensitive topics has been paid. Although the specific tools and methods worked out during the fieldwork are deeply rooted in the theoretical deliberations of other researchers, they emerged primarily as a response to a peculiar research problem and the specificity of a fieldwork situation determined by the realities of small local communities and a limited time frame. The total effect of these methods, understood in terms of amount of information gathered thanks to the practices described above, can hardly be described in quantified categories. Nevertheless, the use of such techniques relatively often helped in the acquisition of useful data. Among all of the practices described in the text, wandering off the main topic of the research was used most frequently. This technique enabled us to gain probably the greatest amount of useful data, although the effective conduct of at least a few interviews was possible thanks probably to the funnel procedure. As a result of the 
implementation of these techniques, we were usually able to acquire data related to such topics as versions of the "difficult past", a perpetrator's identity, social sources of knowledge about the crime, and the respondent's opinion on commemoration of the tragic events. However, we had to deal with two situations where the implementation of these techniques did not result in gaining useful information from a particular respondent. In the first case we faced the respondent's strong resistance, deeply rooted in the imperative to avoid a confrontation with topics that threatened the positive image of the reference group. Since this situation was seen by the respondent as unconditionally too costly in emotional and identity terms, supporting the interviewing process with rapport-building techniques failed. An analogous situation occurred when the respondent felt the interview might seriously threaten his own well-being and social position. Such incidents inspire reflection concerning actions to enable researchers to deal more effectively with a respondent's unwillingness to participate in research evoked by the sensitive character of local studies on attitudes towards the difficult past. The proposed solutions consist of modified variants of the techniques described above as well as alternative methods. The first option includes the implementation of other scenarios involving wandering off the main topic, varied in terms of length and frequency. On the other hand, discursive re-categorization of the victims may be treated as a completely alternative technique. Encouraging respondents to perceive victims as members of a common group category ("members of a given local community", "people") may be potentially helpful in the reduction of their unwillingness to participate in a study ${ }^{3}$. While referring to such a superordinate identity, common to victims, perpetrators, and respondents, the researcher may enable respondents to move beyond perspectives focused on ethnic divisions, to feel a bond with the victims, and, as a result, to change their attitudes towards the interview.

\section{NOTES}

1 For more details on distinction between ingroups and outgroups see Tajfel (1970).

2 A term used in this context by, among others, Schwartz and Kim (2010).

3 On the theory of recategorization and its influence on the reduction of stereotypes and group conflicts, see Gaertner et al. (1993).

\section{REFERENCES}

Bikont, A. (2004). My z Jedwabnego. Warszawa: Prószyński i S-ka.

Branscombe, N. R., Doosje, B.E., \& McGarty, C. (2002). Antecedents and consequences of collective guilt. In D. Mackie, \& E. R. Smith (Eds.), From prejudice to intergroup relations. Differentiated reactions to social group (pp. 49-66). New York: Psychology Press.

Branscombe, N. R., Slugoski, B., \& Kappen, D. M. (2004). The Measurement of Collective Guilt. What It Is and What It Is Not. In N.R. Branscombe, \& B. Doosje 
(Eds.), Collective Guilt. International Perspective (pp. 16-34). New York: Cambridge University Press. https://doi.org/10.1017/CBO9781139106931

Cała, A. (1995). The Image of the Jew in Polish Folk Culture. Jerusalem: Magnes Press. Cała, A. (2005). Wizerunek Żyda w polskiej kulturze ludowej. Warszawa: Oficyna Naukowa.

Campbell, R. (2002). Emotionally Involved. The Impact of Researching Rape. New York: Routledge.

Czyżewski, M. (2008). Debata na temat Jedwabnego oraz spór o "politykę historyczną" z punktu widzenia analizy dyskursu publicznego. In S. M. Nowinowski, J. Pomorski, \& R. Stobecki (Eds.). Pamięć i polityka historyczna. Doświadczenia Polski i jej sąsiadów (pp. 117-140). Łódź: Instytut Pamięci Narodowej.

Daly, K. (1992). The Fit between Qualitative Research and Characteristics of Families. In J. F. Gilgun, K. Daly, \& G. Handel (Eds.), Qualitative Methods in Family Research (pp. 3-11). Newbury Park, CA: Sage Publications.

Dickson-Swift, V., James, E. Kippen, S., \& Liamputtong, P. (2006). Blurring Boundaries in Qualitative Health Research on Sensitive Topics. Qualitative Health Research, 16(1), 853-871. https://doi.org/10.1177/1049732306287526

Dickson-Swift, V., James, E. Kippen, S., \& Liamputtong, P. (2007). Doing sensitive research: what challenges do qualitative researchers face? Qualitative Research, 7(3), 327-353. https://doi.org/10.1177/1468794107078515

Doosje, B. E., Branscombe, N. R., Spears, R., \& Manstead, A. S. R. (2006). Antecedents and Consequences of Group-Based Guilt: The Effects of Ingroup Identification. Group Processes and Intergroup Relations, 9(3), 325-338. https:// doi.org/10.1177/1368430206064637

Forecki, P. (2010). Od „Shoah” do „Strachu”. Spory o polsko-żydowska przeszłość i pamięć. Poznań: Wydawnictwo Poznańskie.

Farberow, N. L. (1963). Taboo topics. New York: Atherton Press.

Gaertner, S. L., Dovidio, J. F., Anastasio, P. A., Bachman, B. A., \& Rust, M. C. (1993). The Common Ingroup Identity Model: Recategorization and the reduction of intergroup bias. European Review of Social Psychology, 4(1), 1-26. https://doi. org/10.1080/14792779343000004

Gross, J. T. (2000). Sąsiedzi. Historia zagłady żydowskiego miasteczka. Sejny: Fundacja Pogranicze.

Gross, J. T. (2001). Neighbors: The Destruction of the Jewish Community of Jedwabne. Princeton: Princeton University Press. https://doi.org/10.1515/9781400843251

Hervé, H., Cooper, B. S., \& Yuille, J. C. (2013). Biopsychosocial Perspectives on Memory Variability in Eyewitness. In B. S. Cooper, D. Griesel, \& M. Ternes (Eds.), Applied Issues in Investigative Interviewing, Eyewitness Memory, and Credibility Assessment (pp. 99-142). New York: Springer. https://doi.org/10.1007/978-1-46145547-9 5

Kasarda, J. D., \& Janowitz, M. (1974). Community attachment in mass society. American Sociological Review, 39(3), 328-339. https://doi.org/10.2307/2094293

Kwiatkowski, P. T. (2008). Pamięć zbiorowa społeczeństwa polskiego $w$ okresie transformacji. Warszawa: Wydawnictwo Naukowe Scholar.

Lee, R. M. (1993). Doing Research on Sensitive Topics. London: Sage Publications. 
Liamputtong, P., \& Ezzy, D. (2005). Qualitative Research Methods. South Melbourne: Oxford University Press.

Liamputtong, P. (2006). Researching the Vulnerable. A Guide to Sensitive Research Methods. London: Sage.

Roccas, S., Klar, Y., \& Liviatan, I. (2004). Exonerating Cognitions, Group Identification, and Personal Values as Predictors of Collective Guilt among Jewish-Israelis. In N.R. Branscombe, \& B. Doosje (Eds.), Collective Guilt. International Perspective (pp. 130-148). New York: Cambridge University Press. https://doi.org/10.1017/ CBO9781139106931.010

Schwartz, B., \& Kim, M. (2010). Introduction: Northeast Asia's Memory Problem. In B. Schwartz, \& M. Kim (Eds.), Northeast Asia's Difficult Past: Essays in Collective Memory (pp. 1-30). London: Palgrave. https://doi.org/10.1057/9780230277427_1

Sieber, J. E., \& Stanley, B. (1988). Ethical and professional dimensions of socially sensitive research. American Psychologist, 43(1), 49-55. https://doi.org/10.1037/0003-066 X.43.1.49

Sułek, A. (2011). Pamięć Polaków o zbrodni w Jedwabnem. Nauka, 3/2011, 339-49.

Tajfel, H. (1970). Experiments in Intergroup Discrimination. Scientific American, 223, 96-102. https://doi.org/10.1038/scientificamerican1170-96

Tokarska-Bakir, J. (2008). Legendy o krwi. Antropologia przesadu. Warszawa: Wydawnictwo WAB.

Tourangeau, R. (2008). Sensitive topics. In P. J. Lavrakas (Ed.), Encyclopedia of Survey Research Methods (pp. 812-813). Newbury Park, CA: Sage Publications.

Mateusz Magierowski holds a $\mathrm{PhD}$ in sociology. His research interests cover collective memory, intergroup reconciliation, ethnic stereotypes and methodology of social research. His publications include „The Collective Memory of Auschwitz and World War II among Catholics in Poland: A Qualitative Study of Three Communities" (History \& Memory, coauthors: Marek Kucia and Marta Duch-Dyngosz) and "Anti-Semitism in Poland: survey results and a qualitative study of Catholic communities" (Nationalities Papers, co-authors: Marek Kucia and Marta Duch-Dyngosz). 
